\title{
Pengalaman Hidup Pasien Stoma Pascakolostomi
}

\author{
La Rangki ${ }^{1}$, Kusman Ibrahim ${ }^{2}$, Aan Nuraeni ${ }^{2}$ \\ ${ }^{1}$ RSUD Kabupaten Muna, Akper Pemkab Muna, ${ }^{2}$ Fakultas Keperawatan Universitas Padjadjaran \\ E-mail:ray_selebes@yahoo.co.id
}

\begin{abstract}
Abstrak
Jumlah pasien pasca kolostomi akibat kanker kolon dan rektal di Indonesia mengalami peningkatan yang signifikan. Kolostomi menyebabkan masalah fisik, psikososial dan spiritual serta ekonomi. Tenaga kesehatan terutama perawat perlu memberikan asuhan keperawatan terhadap pasien pasca kolostomi secara menyeluruh. Penelitian kualitatif terhadap pasien kolostomi sangat diperlukan sebagai upaya untuk mengungkap secara mendalam pengalaman hidup pasien pasca kolostomi dan menemukan new insight, sehingga dapat menambah pengetahuan perawat dalam upaya meningkatkan kualitas asuhan keperawatan yang diberikan pada pasien. Penelitian ini menggunakan metode kualitatif dengan pendekatan fenomenologi. Data didapatkan dengan wawancara mendalam terhadap delapan informan yang merupakan pasien rawat jalan, terdiri dari lima lakilaki dan tiga perempuan, usia antara 30 tahun sampai dengan 73 tahun. Lamanya hidup dengan kolostomi antara empat bulan sampai dengan enam tahun. Analisis hasil wawancara menggunakan metode Colaizzi. Tema yang didapatkan dari pengalaman hidup pasien kolostomi antara lain: keterbatasan dalam melakukan aktivitas sehari-hari, perubahan psikososial informan, perubahan dalam perilaku ibadah dan distres spiritual, perubahan pada aktivitas seksual, sumber-sumber dukungan bagi informan, upaya menjalani hidup dengan kolostomi, adaptasi terhadap perubahan yang terjadi, serta penyulit dalam menjalani hidup dengan kolostomi. Individu yang hidup dengan kolostomi mengalami keterbatasan dalam pemenuhan kebutuhan dasarnya, termasuk perubahan psikososial, distres spiritual dan masalah ekonomi. Berdasarkan penelitian ini, perawat disarankan memberikan dukungan dan dan perhatian pada pasien pasca kolostomi.
\end{abstract}

Kata kunci: Kanker kolorektal, kolostomi, pengalaman hidup

\section{The Life Experiences of Patients with Post Colostomy}

\begin{abstract}
The number of patient with colostomy that it caused by colorectal cancer has been increasing significantlyin Indonesia. Colostomy was affected to physical, psychosocial, spiritual and economic of patients. Health providers, especially nurses need to provide holistic care for post colostomy patients. The aims of this qualitative study were to describe the life experience of post colostomy patients and to explore new insight of nursing interventions. The new insight would increase nurses' knowledge and improve the quality of nursing care. This phenomenological study was obtained data using in-depth interviews to 8 informants. The informants consist of 5 men and 3 women. The characteristic of informants included age between 30-73 years, and the length of time living with a colostomy between 4 months to 6 years. The data were analyzed using the Colaizzi method. This study found several themes such as limited daily activities, psychosocial changes; spiritual distress; changes in sexualactivities;sources of support;live with a colostomy; live adaptation; the burdens living with a colostomy. Living with a colostomy faced problems including the limitation to fulfill their needs, psychosocial changes, spiritual distress, and economic problems. Based on those problems, nurses can give support and attention for post colostomy patients.
\end{abstract}

Key words: Colorectal cancer, colostomy, life experiences 
La Rangki: Pengalaman Hidup Pasien Stoma Pascakolostomi

\section{Pendahuluan}

Pasien dengan diagnosis kanker kolon dan rektal biasanya akan menjalani pembedahan kolostomi. Berdasarkan pengamatan peneliti, pada setiap pasien akan mengalami masalah fisik, psikologis, dan sosial. Masalah fisik yaitu berupa rasa sakit akibat luka operasi kolostomi, sedangkan masalah psikologis berupa rasa malu akibat adanya kantong kolostomi, serta masalah sosial berupa dijauhi dari lingkungan dalam hal ini tetangga pasien.

World Health Organization (WHO) pada tahun 2008 mengatakan bahwa kanker kolon dan rektal merupakan kanker tersering ketiga pada pria dan kedua pada wanita di seluruh dunia. Risiko terjadinya kanker kolon dan rektal secara nyata akan meningkat pada umur 50 tahun dan menjadi dua kali lipat lebih besar pada setiap dekade berikutnya. Karsinoma rektum lebih banyak ditemukan pada laki-laki daripada wanita, tetapi tidak ada perbedaan jenis kelamin yang mencolok pada karsinoma di daerah kolon yang lain. Berdasarkan kajian epidemiologi, disimpulkan bahwa ada pengaruh lingkungan yang sangat besar, khususnya diet, yang berperan nyata sebagai penyebab dari kanker kolon yang berperan lebih besar daripada kanker rektum. Faktor keturunan dapat juga berperan sebagai pencetus timbulnya kanker jenis ini. (Sjamsuhidayat, dkk., 2006).

Peneliti belum menemukan hasil penelitian tentang pengalaman hidup pasien stoma pasca kolostomi di Indonesia. Di luar negeri telah dilakukan penelitian serupa, namun ada perbedaan latar belakang budaya, status sosial dan ekonomi, serta perbedaan paham agama, dalam hal ini ibadah. Hal yang dirasakan antara lain adanya perasaan tidak suci karena adanya lubang stoma, serta perubahan dalam membersihkan yang semula menggunakan tangan kiri, tetapi pada pasca kolostomi harus menggunakan kedua tangan untuk membersihkan kotoran. Kondisi ini merupakan faktor penyebab distres spiritual bagi pasien dalam menjalani hidup dengan kolostomi.

Bagi muslim tangan kiri merupakan tangan yang digunakan untuk membersihkan yang kotor-kotor dan tangan kanan digunakan untuk makan dan menyentuh yang bersihbersih (Black, 2004). Hal ini merupakan penyebab kesulitan dalam mengelola stoma. Perawat stoma membutuhkan kerjasama dengan pasien untuk melatih penggunaan alat yang tepat dengan menggunakan tangan kiri saja (Vujnovich, 2008). Berdasarkan pertimbangan tersebut, maka peneliti ingin menggali pengalaman hidup pasien pasca kolostomi, yang kemungkinan besar akan muncul pengalaman hidup yang berbeda dengan pasien kolostomi di negara lain.

Berdasarkan pengalaman hidup pasien tersebut diharapkan menjadi inspirasi bagi pasien lain yang akan menjalani kolostomi dan juga akan menjadi dasar dalam pemberian asuhan keperawatan yang lebih komprehensif bagi pasien stoma.

\section{Metode Penelitian}

Penelitian ini merupakan penelitian kualitatif fenomenologi. Penelitian ini dilakukan terhadap delapan informan yang merupakan pasien rawat jalan dengan menggunakan teknik purposive sampling. Pengumpulan data dilakukan melalui wawancara mendalam (in-depth interview), dengan menggunakan alat perekam suara (voice recorder). Analisis data menggunakan metode Colaizzi. Pada penelitian ini juga memperhatikan keandalan data dan prinsip etika penelitian.

\section{Hasil Penelitian}

Pada penelitian ini diperoleh delapan tema yang merupakan kompilasi dari seluruh pengalaman informan yang hidup dengan stoma yakni: keterbatasan dalam aktivitas sehari-hari, perubahan psikososial informan, keterbatasan dalam ritual keagamaan atau distres spirual, keterbatasan dalam aktivitas sosial, sumber-sumber dukungan bagi informan, upaya menjalani hidup dengan stoma, adaptasi terhadap perubahan yang terjadi, dan penyulit dalam menjalani hidup dengan kolostomi.

Tema pertama dalam penelitian ini yaitu keterbatasan dalam aktivitas sehari-hari. Informan dalam penelitian ini mengalami kondisi yang serba terbatas untuk melakukan segala sesuatu dalam kehidupannya, yakni sebagai berikut: keterbatasan dalam makan 
La Rangki: Pengalaman Hidup Pasien Stoma Pascakolostomi

dan minum, keterbatasan dalam beraktivitas dan bekerja, keterbatasan dalam istrahat dan tidur, keterbatasan dalam buang air kecil, dan keterbatasan untuk mandi, merawat luka dan ganti kantong.

Penelitian ini menemukan bahwa informan mengalami keterbatasan dalam memilih makanan. Seperti yang dikeluhkan oleh beberapa informan dalam penelitian ini.

“....saya hindari makan pedas, asam dan tidak minum susu, karena selalu mencret...."(I.5) , “......makan nggak masuk, saya dikasih air saja satu sendok, sama susu sedikit aja, trus dikasih bubur tapi nggak masuk......" (I.3)

Pada penelitian ini juga ditemukan bahwa informan mengeluhkan adanya kesulitan yang terjadi pada diri informan yakni kolostomi membatasi informan dalam melakukan aktivitas. Seperti pernyataan mereka berikut: "...kondisi saya sangat parah, badan lemah setelah operasi....." (I.1)

"........saya terlentang 20 hari setelah operasi, saya tidak bisa bergerak secara bebas" (I.1)

Keterbatasan dalam istrahat dan tidur juga dirasakan oleh beberapa informan dalam penelitian ini. Berikut pernyataan informan: ".......saya sering terbangun tengah malam.....pikir kedepannya gimana bila saya meninggal kasian anak-anak saya..." (I.6)

Informan juga mengalami keluhan dalam hal buang air kecil, seperti yang dikemukakan oleh beberapa infoman pada penelitian ini.

".......saya rasakan sakit pada kandung kencing, trus pasang selang sampai sekarang....." (I.2)

“......kalau kencing sakit sekali,lama-lama tidak bisa kencing, trus pasang kateter sampai sekarang" (I.7)

Muncul juga pengalaman informan dalam pemenuhan perawatan diri berupa kesulitan untuk merawat luka dan mengganti kantong. Berikut ungkapan informan:

“...pertama saya selalu dibantu oleh istri untuk mandi, rawat luka dan ganti kantong trus sebulan saya bisa mandi sendiri.." (I.2)

Tema kedua dari hasil penelitian ini yaitu perubahan psikososial informan. Selain perubahan secara fisik, muncul juga perubahan secara psikologis dan dalam berinteraksi sosial, berupa adanya perasaan takut, stres dan cemas serta perubahan pada komponen konsep diri berupa perubahan pada citra tubuh, peran diri, dan ideal diri. Pada kategori ini terungkap beberapa hal yaitu: adanya rasa takut akibat kanker, perubahan pada citra tubuh, perubahan pada peran diri, perubahan pada ideal diri, perubahan pada harga diri, dan perubahan pada interaksi sosial.

Ketakutan pada informan muncul setelah didiagnosis kanker kolon dan rektum. Stres juga dirasakan akibat hidup dengan stoma. Berikut ungkapan informan:

“....saya sering dengar tetangga bilang, kalo operasi dua kali pasti mati katanya, saya takut sekali..." (I.1)

".....kata dokter saya kena kanker, saya takut mati, persiapan saya belum banyak bila mati sekarang...."(I.4)

Pada penelitian ini juga ditemukan informan yang mengalami perubahan pada citra tubuh. Berikut ungkapan informan:

".....saya merasa tidak sempurna lagi tubuh saya, dulu masih bisa buang air besar dianus tapi sekarang saya harus buang air besar dikantong, rasanya gimana yah, tidak enak sekali hidup seperti ini..." (I.2)

Beberapa dari informan juga mengalami perubahan pada peran diri, sebagaimana ungkapan informan berikut ini:

“.... rasanya saya tidak enak juga sama istri yang mencari nafkah, saya hanya bisa bantu ngantar pake motor, anak selalu minta jajan, sedangkan saya tidak bisa kerja lagi seperti dulu, bingung juga...." (I.3)

Informan memiliki ideal diri yang baik setelah mengalami operasi kolostomi. Sebagaimana ungkapan informan berikut ini: “.....saya tidak bisa kerja lagi seperi dulu tapi saya akan berharap bisa sembuh dari sakit saya, terus saya akan bikin tali pinggang untuk pasang kantong kolostomi, mudahmudahan bisa laku kalo dijual, kan menolong juga orang lain...."(I.3)

Pada penelitian ini ditemukan informan yang merasa malu dan mengalami harga diri rendah. Berikut ungkapan informan:

".....saya malu dengan kantong di perut, semula saya bisa buang air besar di anus trus sekarang saya buang air besar di lubang perut...." (I.2)

Perubahan pada aspek sosial juga dialami oleh beberapa informan. Beberapa informan merasa malu dalam berinteraksi dengan tetangga dan lingkungan. Berikut ungkapan informan: 
La Rangki: Pengalaman Hidup Pasien Stoma Pascakolostomi

“...saya malu ketemu sama tetangga, ada kantong diperut..." (I.2)

"....saya risih bila keluar rumah, soalnya kentut terus, tidak enak juga kan didengar orang, apalagi orang baru...."(I.3)

“...dulu saya rajin ngaji, setelah itu risih, karena ada bau dari kantong kolostomi saya...." (I.5)

Pada penelitian ini informan berusaha mengatasi perubahan psikososial terkait dengan rasa takut, stres hidup dengan kolostomi serta perubahan pada citra tubuh, peran dan ideal diri. Hal tersebut dilakukan dengan memperbanyak interaksi dengan orang lain, termasuk menguatkan diri untuk dapat menjalani hidup dengan kolostomi, juga penguatan nilai-nilai spiritual untuk mendapatkan ketenangan batin dalam kehidupannya. Berikut ungkapan informan:

“....setelah operasi, saya stres dan risih dengankondisikantongdiperut, trus sayajuga malu ketemu tetangga, berusaha tetap tegar dengan kondisi ini, saya menganggapnya biasa saja, trus saya sering curhat sama teman sesama pasien stoma, kami saling berbagi cerita, trus berdoa sama yang maha kuasa, demi kesembuhan, akhirnya saya kuat lagi, dan tetap sabar" (I.2),

Tema ketiga yang didapatkan dari hasil penelitian ini yaitu keterbatasan dalam ritual keagamaan atau distres spiritual Hidup dengan kolostomi juga menyebabkan perubahan informan dalam kegiatan ibadah sehingga mengalami distres spiritual, hal ini dialami oleh semua informan. Pada tema ini, informan mengungkapkan bahwa terdapatnya perubahan pada perilaku ibadah dan pertentangan pada keyakinan informan.

Pada penelitian ini ditemukan bahwa pada awalnya informan merasa risih bila salat dengan kantong yang melekat pada dinding perutnya. Berikut ungkapan informan:

"...saya sejak awal saya merasa malu bertemu Tuhan soalnya saya rasa diri tidak suci, kentut terus saat sembahyang, kadang saya kena mencret, trus saya juga tidak bisa sujud karena takut kantong kolostomi saya bocor dan tertarik, makanya saya tidak berani sholat, sekarang ini saya sholat dengan berdiri saja tanpa sujud..." (I.4) "....saya risih bila sholat... menghadap sama Tuhan dengan kondisi begini..” (I.2)

".....saya belum sholat jumat sejak operasi empat bulan yang lalu, masih rasa risih juga...." (I.6)

Pada penelitian ini juga peneliti menemukan informan yang mengalami distres pada keyakinan agama yang dianut, yakni munculnya perasaan tidak suci untuk menghadap Tuhan. Perawatan kantong kolostomi dengan menggunakan tangan kanan juga menjadi distres bagi informan, yang selama ini bila dalam keadaan sehat selalu menggunakan tangan kiri. Namun demikian setelah dijelaskan oleh suami yang juga pemuka agama, maka informan dapat menerima kondisinya. Berikut ungkapan informan:

"......saya merasakan hidup yang berat saat awal operasi, saya yakin kalo menghadap Tuhan harus bersih, sementara saya tidak dalam keadaan suci, trus saya bersihkan kotoran dikantong kolostomi dengan dua tangan, kalo dalam agama kan tidak boleh, saya stres juga pak, gimana nih pak, trus suami saya bilang,tidak apa-apa karena memang beginilah kondisi mama, insya allah Tuhan akan memahami kondisi mama katanya, jadi saya kuat lagi pak..." (I.4)

Tema keempat dari penelitian ini yaitu adanya keterbatasan dalam aktivitas seksual Hidup dengan kolostomi juga berdampak pada perubahan aspek seksual yang dialami oleh sebagian informan. Beberapa informan mengalami disfungsi ereksi akibat dari efek terapi sinar. Berikut ungkapan informan:

“...saya takut untuk hubungan badan, karena berpengaruh pada kantong stoma saya..."(I.2)

"...setelah sinar, saya alami yang orang sebut disfungsi ereksi,jadi sulit hubungan badan..." (I.1)

"....setelah operasi saya alami kesulitan ereksi, tpi lama-lama bisa pulih lagi, mungkin karena banyak pikiran jadi berpengaruh juga..." (I.3)

Tema kelima dari hasil penelitian ini yaitu adanya sumber-sumber dukungan bagi informan. Pada penelitian ini setiap informan banyak mendapatkan dukungan dari berbagai pihak, dukungan tersebut sangat bermanfaat bagi kelangsungan hidup informan setelah menjalani hidup dengan kolostomi. Pada tema ini teridentifikasi tiga subtema yaitu dukungan keluarga, dukungan kelompok, dan dukungan dari dokter dan perawat. 
La Rangki: Pengalaman Hidup Pasien Stoma Pascakolostomi

Pada penelitian ini semua informan mendapatkan dukungan dari keluarga, mulai dari sejak didiagnosis kanker kolon dan rektal hingga setelah operasi kolostomi. Sebagaimana ungkapan informan berikut ini:

"....sejak dari rumah sakit ketika dirawat saya selalu ditemani, termasuk setelah operasi, saya dilatih duduk, terus berdiri kemudian berjalan dan selalu dimotivasi untuk tetap kuat..."(I.2)

Selain mendapat dukungan dari keluarga, informan juga mendapat dukungan dari teman-teman kerja. Sebagaimana pernyataan informan berikut:

“.....saya ikut dalam perhimpunan pasien stoma Jabar, untuk berbagi informasi” (I.1)

Informan juga mendapatkan dukungan dari keluarga dan teman kerja. Informan juga mendapat dukungan dari dokter dan perawat. Berikut ungkapannya:

“.....saya mendapatkan dukungan dari dokter dan perawat dan mengajarkan cara ganti kantong...." (I.2)

Pada penelitian ini juga diperoleh tema lain yang muncul yaitu adanya data-data tentang bagaimana upaya yang dilakukan informan saat memulai hidup dengan stoma. Secara umum upaya yang dilakukan oleh informan terdiri dari penguatan secara spiritual dan penguatan dengan motivasi diri sendiri.

Informan dalam penelitian ini melakukan upaya dengan meningkatkan nilai-nilai spiritual sebagai upaya untuk menerima kondisinya, sebagai bagian dari cobaan yang diberikan oleh Tuhan. Berikut ungkapan informan:

".....saya ikut dalam pengajian lingkungan, ibadah saya makin baik malah sekarang ini, soalnya saya takut mati karena persiapan saya belum banyak, jadi dengan kondisi ini saya tetap menerima dan saya jadi kuat lagi, soalnya kalo hanya dirumah saya banyak stress, jadi saya banyak bergaul, jadi kuat lagi....." (I.4)

Informan dalam penelitian ini melakukan upaya dengan meningkatkan penguatan pada jiwanya sebagai upaya untuk menerima kondisinya, sebagai bagian dari hidup yang harus dijalani. Berikut ungkapan informan: ".....awalnya saya bingung harus hidup dengan kondisi begini, trus saya ingin cepat sembuh dan lihat anak dan suami juga, kasian kalo saya bikin susah mereka, jadi saya harus kuat dalam menjalani hidup ini, trus saya selalu baca-baca informasi di internet, banyak saya dapat informasi untuk rawat luka dan gani kantong...." (I.8)

Pada penelitian ini ditemukan ungkapan beberapa informan yang mengalami perubahan setelah menjalani pembedahan kolostomi serta upaya adaptasi yang dijalani dalam mengatasi setiap hal yang terjadi. Pada penelitian ini peneliti menggolongkan kemampuan adaptasi bagi informan berdasarkan kelompok masalah yang timbul yakni adaptasi fisik dan psikososial.

Pada penelitian ini semua informan mengalami kesulitan untuk menggerakkan badan akibat kelemahan yang dirasakan setelah pembedahan. Keluhan lemah dirasakan hingga 20 hari bahkan hingga dua bulan. Sebagaimana ungkapan informan berikut ini: ".....saya merasakan lemah yang parah setelah operasi sampai 20 hari setelah operasi baru bisa saya bangun, mungkin karena usia saya sudah tua, makanya saya baring terus...."(I.1)

Pada penelitian ini juga diperoleh informasi bahwa informan melakukan adaptasi dengan latihan fisik yang dibantu oleh keluarga dan orang terdekat. Berikut ungkapan informan: “......setelah 20 hari baru saya mulai latihan duduk di tempat tidur, trus saya dilatih untuk berdiri disamping tempat tidur, hingga akhirnya saya latihan jalan dikamar dan diluar kamar, latihan selalu dibantu istri dan anak..." (I.I)

Pada penelitian ini juga ditemukan ungkapan informan mengenai adaptasi terhadap perubahan yang terjadi secara psikologis, terutama terkait dengan perubahan konsep diri citra tubuh akibat operasi kolostomi. Informan merasakan sesuatu yang berbeda dengan sebelum operasi, dimana saat setelah operasi informan merasa tidak nyaman dengan kantong kolostomi yang menempel pada dinding perutnya. Berikut ungkapan informan:

“..... setelah operasi saya merasa risih dan malu bertemu dengan orang lain, saya butuh waktu tiga bulan untuk bisa menerima kondisi saya, berat rasanya mendapat cobaan seperti ini pak..." (I.2)

Pada penelitian ini juga ditemukan adaptasi informan terhadap proses interaksi 
La Rangki: Pengalaman Hidup Pasien Stoma Pascakolostomi

sosial dengan lingkungan dan masyarakat disekitarnya. Sebagian besar informan membutuhkan waktu yang bervariasi dan dukungan keluarga sangat besar terhadap kemampuan tersebut. Berikut ungkapan informan:

“.....setelah operasi selama dua bulan tidak pernah keluar rumah, soalnya saya malu sekali sama orang lain, saya pikir tidak mungkin begini terus, makanya saya mulai kedatangan tamu dari tetangga trus teman dekat, hingga akhirnya saya mulai bergaul dengan orang lain, saya selalu dikuatkan oleh mereka, agar saya jangan menyendiri dan selalu berbagi cerita kata perawat dirumah sakit juga begitu, makanya saya mulai masuk kerja lagi setelah tiga bulan pasca operasi, meskipun kerjaan saya tidak seberat dulu, sekarang saya hanya duduk saja sebagai satpam...."(I.2)

Pada penelitian ini juga ditemukan terdapat beberapa ungkapan informan yang mengalami kondisi yang dapat menambah kesulitan dalam hidup dengan kolostomi, yaitu kesulitan ekonomi, kurangnya informasi dari petugas kesehatan, komplikasi pascakolostomi, pengalaman terhadap rasa nyeri, dan akses pelayanan kesehatan yang jauh.

Perubahan pada aspek ekonomi juga dialami oleh semua informan. Sebagian besar biaya operasi dijamin oleh asuransi, namun dalam perjalanannya tetap menggunakan biaya pribadi untuk biaya belanja kantong dan biaya hidup lainnya. Berikut ungkapan informan: “....saya harus terapi kemo kelas tinggi tapi tidak masuk jaminan,saya nunggu informasi dari dokter dulu kata perawat. sulit juga kalau tidak ada pekerjaan tetap.." (I.3)

"....saya jual motor dan emas untuk biaya obat dan beli kantong..." (I.7)

"...saya sulit kerja saat ini, kebutuhan rumah tangga hanya dari istri...” (I.3)

Selain penyulit faktor finansial bagi informan, juga kurangnya informasi dari pemberi pelayanan kesehatan terhadap informan. Tenaga kesehatan yang berperan adalah dokter dan perawat. Berikut ungkapan informan:

“.....saya tidak tahu, mau dioperasi apa,saya sadar rupanya begini kondisi saya..." (I.6)

".....seharusnya dokter itu bilang dulu kesaya, tapi hanya bilang sama keluarga, jadi saya bingung dengan kondisi ini...." (I.6) ".....dokter digarut jarang bicara, beda dengan dokter di hasan sadikin yang suka menjelaskan..." (I.7)

Terdapat informan yang mengalami keluarnya usus dari lubang kolostomi pasca menjalani bedah kolostomi, sebagaimana ungkapan informan berikut:

"....setelah operasi usus saya keluar dari lobang dinding perut, mungkin terlalu banyak jalan dan naik motor sama istri..."(I.3)

Pengalaman terjadinya iritasi pada kulit sekitar stoma juga dialami oleh beberapa informan. Hal ini terjadi akibat dari rembesan produksi feses yang mengenai area kulit sekitar stoma. berikut pernyataan informan:

"....kulit saya iritasi akibat isi kantong merembes dikulit sekitar kantong stoma...." (I.1)

“....kalo ganti kantong saya ada lecet dikulit..." (I.6)

Pada penelitian ini informan mengalami efek samping kemoterapi maupun radioterapi. Informan mengalami mencret, mual, muntah, bahkan rambut rontok. Berikut ungkapan mereka:

"saya jalani kemoterapi rasanya berat pada kemo yang kelima saja, kalo siklus awal saya tidak merasakan apa-apa, trus pada kelima saya merasakan mual, muntah dan rambut rontok, biasa bangun pagi bantal banyak rambutnya, tapi tidak sampai botak" (I.3)

Pengalaman rasa nyaman nyeri juga dialami sebagian besar informan. Rasa nyeri ini muncul akibat adanya luka sayatan operasi kolostomi. Berikut ungkapan informan:

"....empat hari setelah bius saya hilang, maka saya merasakan sakit sekali, saya malah mengigau karena terlalu sakitnya, terus saya juga tidak bisa tidur, gerakan badan juga sakit, akhirnya saya dikasih obat supaya rasa nyerinya hilang...." (I.1)

Pengalaman yangjuga dialamiolehinforman dalam penelitian ini adalah hambatan dalam akses pelayanan kesehatan bagi informan yang telah menjalani pembedahan kolostomi. “....usus saya pernah keluar, trus saya harus ke rumah sakit, puskesmas tidak ada alat katanya untuk tindakan, aduh susah pak, harus ke rumah sakit dulu...." (I.3)

Semua informan juga diharuskan menjalani kemoterapi dan radioterapi di Rumah Sakit Hasan Sadikin. Setiap tindakan kemoterapi 
La Rangki: Pengalaman Hidup Pasien Stoma Pascakolostomi

maupun sinar tidak dapat dilakukan di Rumah Sakit Daerah, dengan alasan belum ada fasilitas untuk terapi tersebut. Kondisi tersebut banyak dikeluhkan oleh informan:

“...habis saya operasi di garut, dirujuk ke bandung untuk kemo, jauh sekali pak,saya masih lemah harus ke bandung..." (I.5)

".....tiga bulan setelah operasi saya dirujuk di hasan sadikin untuk kemo, saya harus sewa kamar kos tiap bulan enam ratus ribu...." (I.7)

\section{Pembahasan}

Penelitian ini menunjukkan hasil bahwa informan mengalami keterbatasan dalam melakukan aktivitas atau kegiatan harian. Setiap manusia menginginkan untuk hidup secara bebas dalam melakukan segala sesuatu yang diinginkannya, namun tidak demikian pada pasien stoma pascakolostomi. Pasien stoma mengalami banyak perubahan. Kondisi ini dapat menjadikan pasien merasa terbatas untuk melakukan segala sesuatu.

Beberapa informan menyatakan bahwa dirinya mengalami keterbatasan memilih jenis makanan. Perubahan tersebut berupa makan bubur, menghindari makanan pedas, bumbu-bumbu, asam dan susu, juga terjadi penurunan nafsu makan. Dampak dari hal tersebut menyebabkan terjadinya keraguan memilih makanan. Kondisi ini dapat menurunkan status kesehatan pada informan, sebaiknya informan juga tetap mencoba untuk mengonsumsi makanan yang ada untuk memperbaikan kondisi kesehatan pasien. Hal ini sebagaimana pernyataan Vujnovich (2008) bahwa terdapat banyak isu yang penting untuk didiskusikan dengan pasien stoma, termasuk tentang diet.

Manajemen diet pascakolostomi sangat penting dilakukan pada pasien yang bertujuan untuk mencegah terjadinya sumbatan pada bagian usus besar pascabedah, meningkatkan proses penyembuhan pada luka operasi dan meminimalkan terjadinya gangguan pada saluran pencernaan, seperti kentut, diare, kostipasi, dan bau stoma. Pada kondisi postoperation sangat penting makanan tinggi kalori, tinggi protein untuk penyembuhan luka, dan rendah lemak (Akbulut, 2011).
Pada penelitian ini beberapa informan mengalami kesulitan melakukan aktivitasnya sehari-hari dalam pemenuhan kebutuhannya, sehingga sebagian besar informan dibantu oleh keluarga terutama oleh suami ataupun istri dari informan. Kesulitan untuk melakukan aktivitas ini membuat informan menjadi ketergantungan pada keluarganya, hal ini akan berdampak pada terhambatnya keluarga dalam tugas harian mereka. Hal ini sesuai dengan hasil penelitian yang dilakukan Karadag, dkk., (2002) yang menyimpulkan bahwa kolostomi memiliki dampak negatif yang sangat berat pada kualitas hidup pasien. Sedangkan pada penelitian lain juga menemukan bahwa stoma berpengaruh pada keterbatasan melakukan aktivitas sehari-hari dan pergaulan sosial (Joshland, Brennan, Anastasiou, \& Brown, 2011). Pasien dengan stoma menghadapi beberapa stres khusus, yakni kemungkinan terisolasi, harga diri yang rendah, gangguan citra tubuh, dan memiliki rasa tidak kompeten (Black, 2004).

Terbatasnya pemenuhan istrahat dan tidur juga dialami oleh beberapa informan pada penelitian ini. Pada informan tujuh, penyebab susah tidur lebih diakibatkan karena adanya rasa sakit dan pegal pada punggung dan paha. Sedangkan pada informan lima sulit tidur diakibatkan oleh banyak memikirkan masa depan keluarga bila dirinya meninggal akibat penyakit yang dialaminya. Informan yang mengalami kesulitan tidur ini berdampak pada perubahan kesehatan mental informan yang juga berdampak buruk pada kondisi fisik secara keseluruhan.

Perubahan pada aspek fisik yang juga dialami oleh pasien stoma pascakolostomi adalah pengalaman eliminasi urin berupa tidak bisa buang air kecil juga ditemukan pada penelitian ini, seperti yang dialami oleh informan dua dan informan tujuh. Perubahan pada eliminasi berupa disuria, dimana klien merasakan kesulitan kencing dan rasa sakit ada kandung kemih. Penelitian yang dilakukan Lone, dkk. (2007) dengan metode prospektif, terhadap 249 pasien kanker kolorektal dengan lama berkisar 3, 6, 12, 24 bulan setelah operasi, selanjutnya dilakukan follow up, sehingga diperoleh hasil bahwa pasien dengan stoma memiliki masalah pada perkemihan berupa sulit dan terasa sakit saat 
La Rangki: Pengalaman Hidup Pasien Stoma Pascakolostomi

berkemih.

Keterbatasan lain yang juga dapat dialami oleh informan setelah menjalani tindakan kolostomi diantaranya yaitu kesulitan dalam mandi dan untuk melakukan perawatan luka. Informan mengalami kesulitan untuk mandi dan merawat luka dan ganti kantong dialami beberapa informan, yakni informan tiga, informan lima, infirman enam, informan tujuh, dan informan delapan. Perubahan pada pola perawatan diri ini seperti mandi dibantu oleh istri dan mandi seminggu sekali, hal ini dialami informan tiga. Selanjutnya informan tujuh dan delapan, semua kebutuhan dibantu keluarga. Sejalan dengan penelitian yang dilakukan oleh White (1997) bahwa pasien stoma khawatir untuk melakukan penggantian kantong stoma.

Selain adanya keterbatasan dalam menjalani hidup dengan kolostomi, juga terjadi perubahan pada aspek psikologis yang dialami oleh sebagian besar informan pada penelitian ini. Beberapa informan merasakan ketakutan terhadap penyakit yang dialami. Selain itu, informan juga mengalami rasa stres hidup dengan adanya kantong kolostomi pada dinding perutnya. Selain itu, munculnya rasa risih hidup dengan kantong juga dilamai oleh informan dua. Hal ini sesuai dengan penelitian yang dilakukan oleh White (1997) pasien dengan stoma mengalami perubahan psikososial yang berkaitan dengan kolostomi. Penelitian ini menunjukkan sekitar 25\% pasien stoma mengalami kecemasan, depresi, dan emosi negatif setelah pembedahan stoma. Penelitian tersebut juga membuktikan bahwa perawat perlu memberikan edukasi dan konseling berupa penguatan jiwa dan mental pasien dalam menjalani hidup pascakolostomi. Studi yang dilakukan oleh McKenzie, dkk., (2006) menemukan bahwa pasien dengan stoma masih merasa tidak nyaman lebih dari 4 bulan setelah operasi.

Pasien dengan stoma juga mengalami keterbatasan dalam hal menjalankan ritual keagamaan atauberibadah. Halinidialamioleh semua informan dalam penelitian ini dimulai dari awal setelah menjalani pembedahan, hingga saat dilakukan penelitian, beberapa informan masih mengalami keterbatasan dalam menjalankan ibadah, terlebih untuk salat berjamaah di masjid. Keterbatasan dalam menjalankan ibadah ini disebabkan oleh banyak hal, diantaranya adanya perasaan risih akibat sering kentut termasuk adanya bau yang timbul dari kotoran yang keluar melalui lobang stoma yang dimilikinya. Termasuk adanya rasa malu bila menghadap pada Tuhan dalam kondisi tidak merasa suci, dan adanya pertentangan perasaan dan paham agama yang tidak boleh membersihkan kotoran dengan tangan kanan juga dialami oleh informan.

Pasien muslim yang telah menjalani pembedahan kolostomi, biasanya mengalami berbagai masalah dalam ritual keagamaan. Kebanyakan pasien mengalami frustrasi akibat kondisinya. Peningkatan kesejahteraan spiritual akan dicapai bila adanya peran dari tokoh agama yang dapat dijadikan tempat untuk bertanya bagi pasien, serta dukungan secara psikologis dari tenaga kesehatan terutama dokter dan perawat sejak sebelum operasi hingga setelah operasi, hal ini akan meningkatkan kepercayaan diri pasien dalam menjalani hidup dengan kolostomi, termasuk melakukan ritual kegamaan dan dapat mengurangi terjadinya masalah yang berkaitan dengan spiritual (Khan, Jamal, Rashid, \& Ahmad, 2011).

Latar belakang budaya juga dapat berperan penting dalam kehidupan pasien, termasuk keyakianan pasien secara pribadi maupun agama, persepsi mereka terhadap pemulihan, perilaku dan konsep serta sikap terhadap penyakit. Dalam hal ini, perawat harus mampu mengombinasikan ungkapan informasi dari informan secara terbuka, pertanyaan dengan menghargai pasien dan keluarga serta mempunyai komitmen untuk merespons secara fleksibel dan konstruktif (Black, 2004). Pada budaya muslim, tangan kiri merupakan tangan yang digunakan untuk membersihkan yang kotor-kotor dan tangan kanan yang digunakan untuk makan dan menyentuh yang bersih-bersih (Black, 2004). Hal ini merupakan penyebab kesulitan dalam mengelola stoma dan perawat stoma membutuhkan kerjasama dengan pasien untuk melatih menggunakan alat yang tepat dengan tangan kiri saja (Vujnovich, 2008).

Beberapa informan mengatakan bahwa informasi yang didapatkan dari lembaga majelis ulama Indonesia tetap menganjurkan 
untuk melakukan ibadah walaupun dalam kondisi pasca kolostomi. Hal ini penting bagi perawat dalam memberikan konseling bagi informan tentang pentingnya ibadah dalam semua kondisi termasuk adanya kantong kolostomi yang melekat pada dinding perut informan, tidak menghalangi perilaku ibadah bagi setiap informan. Beberapa informan dapat menjalankan ibadah dengan tetap berpikir positif terhadap cobaan yang dialami, bahkan informan menilai hal ini merupakan saat yang tepat untuk meningkatkan kualitas ibadahnya, namun sebagian yang lainya belum dapat beribadah hingga empat bulan pasca operasi.

Kondisi informan yang sulit untuk melakukan ibadah akibat adanya kantong kolostomi atau adanya distres spiritual akibat pertentangan batin dengan adanya perasaan tidaksuciuntukibadahdengankeinginanuntuk tetap beribadah, maka menjadi penting untuk dilakukan pendampingan dari profesional kesehatan untuk memberikan bimbingan dan konseling bahwa pasien stoma tetap dapat melakukan ibadah. Pendapat Majlis Fatwa Dewan Da'wah Indonesia (2009) dalam keputusannya bahwa orang yang sakit, safar, terpaksa, dan mereka yang dalam kesulitan adalah ahlul-a'dzar yang Allah \& Rasul-Nya beri kemudahan dan keringanan-keringanan dalam hal ibadat dan mu'amalah. Ketentuan tersebut termasuk bagi penderita penyakit stoma yang mengharuskannya memakai kantong khusus sebagai pengganti saluran pembuangan hajat. Pelaksanan ibadah pada pasien stoma dikuatkan dengan firman Allah SWT.

Kekuatan spiritual adalah segala sesuatu tentang hubungan manusia dengan sumber kekuatan hidup atau yang Maha Memiliki kekuatan (Taylor, Lilis, \& Lemone, 1997). Penguatan tentang spiritual juga dinyatakan oleh Craven dan Hirnle (2007) yang mengatakan bahwa spiritualitas adalah kualitas atau kehadiran dari proses meresapi atau memaknai, integritas, dan proses yang melebihi kebutuhan biopsikososial dimana suatu kualitas dari proses menjadi lebih religius, berusaha mendapatkan insprasi, penghormatan perasaan kagum, memberi makna dan tujuan yang dilakukan oleh individu yang percaya maupun yang tidak percaya kepada Tuhan.
Selain perubahan secara fisik, juga muncul perubahan pada aspek seksual yang dialami oleh sebagian besar informan pada penelitian ini. Beberapa informan merasakan takut untuk hubungan badan karena akan menimbulkan masalah pada kantong, sehingga tidak ingin melakukan hubungan badan. Selain itu juga informan mengalami banyak pikiran mengenai hidup dengan kantong kolostomi pada dinding perutnya sehingga mengurangi minat dan hasrat seksual termasuk berdampak pada disfungsi ereksi.

Selanjutnya juga timbul rasa malu dan minder pada pasangan akibat adanya kantong pada dinding perut informanseperti yang dialami oleh informan dua. Munculnya rasa risih atau minder dengan pasangan berdampak pada kesulitan untuk pemenuhan kebutuhan seksual, hal ini akan berakibat pada munculnya rasa tidak nyaman terhadap pasangan masingmasing. Hal ini membutuhkan dukungan informasi yang cukup bagi setiap pasangan untuk dapat menyelesaikan setiap masalah yang muncul dari pasangan berkaitan dengan seksual. Sehingga akan diperoleh kehidupan seksual yang sehat bagi pasien dengan stoma. Kecemasan tentang kemampuan untuk melakukan hubungan seksual dan perasaan khawatir terhadap peralatan stoma selama hubungan seksual, dapat menimbulkan penolakan keintiman dengan pasangannya (Black, 2004).

Pada penelitian ini, dukungan sosial juga dirasakan oleh informan setelah menjalani operasi kolostomi. Dukungan didapatkan dari keluarga, teman kerja, dan tetangga di tempat tinggal. Dukungan dari keluarga ini sangat penting, mengingat keluarga dituntut untuk memberikan dukungan yang lebih besar dibandingkan dengan dukungan dari orang lain. Dukungan keluarga meliputi dukungan terhadap sikap, tindakan, dan penerimaan keluarga terhadap informan setelah operasi kolostomi. Menurut The National Council for Palliative Care (NCPC) (dalam Joshland, dkk., 2011) mengemukakan bahwa keluarga merupakan orang yang selalu dilibatkan dalam setiap tindakan pemberian pelayanan oleh tenaga kesehatan. Keluarga selalu mendampingi informan dalam setiap kondisi dan perawatan yang dimulai dari prediagnosis, saat proses penegakkan diagnosis dan pengobatan, selama 
La Rangki: Pengalaman Hidup Pasien Stoma Pascakolostomi

sakit atau bahkan sampai kematian.

Pada penelitian ini ditemukan informasi mengenai bagaimana individu melakukan strategi koping setelah hidup dengan stoma. Strategi koping yang digunakan lebih banyak mengarah pada mencari teman sesama penderita stoma, ikut dalam perhimpunan stoma, termasuk selalu mencari berita-berita dari internet dengan tujuan untuk berbagi pengalaman dan informasi sehingga dapat mempercepat informan dalam menerima kondisinya. Informan mengatakan bahwa banyak keuntungan bila selalu bergaul dengan sesama penderita, sebab informan saling berbagi informasi maupun perasaan masingmasing, sehingga mereka memiliki kekuatan yang lahir dari diri mereka sendiri. Dengan demikian, informan memiliki kemampuan untuk hidup dengan stoma.

Menurut Vujnovich (2008), mekanisme koping dikategorikan menjadi dua yaitu koping aktif (active coping) dan koping yang menghindar (aviodant coping). Koping aktif akan dapat memecahkan suatu masalah dengan berbagai perencanaan dan tindakan seperti pencarian informasi dan dukungan dan atau pemilihan jalan keluar terhadap suatu kejadian sebagai jalan untuk adaptasi. Sedangkan koping menghindar merupakan karekteristik terjadinya kegagalan dalam menghadapi kejadian stres dengan melakukan berbagai kegiatan atau aktivitas yang buruk, seperti pemakaian obat, akohol sehingga sangat buruk dalam hal melakukan adaptasi terhadap stres.

Pada penelitian ini ditemukan sebagian besar informan mengalami perubahan pada fisik maupun psikososial yang berdampak pada kondisi informan secara umum. Beberapa informan melakukan upaya dalam mengatasi dan menerima kondisinya dengan berbagai cara dan pendekatan. Secara umum, semua informan membutuhkan dukungan yang optimal baik dari keluarga dan orang terdekat dalam upaya untuk menjalani hidup dengan kolostomi. Tindakan pembedahan yang dilakukan pada pembentukan stoma merupakan masalah yang besar dalam hidup pasien sehingga membuntuhkan penyesuaian psikologis yang cukup. Pasien mengalami masalah psikologis sampai tingkat tertentu baik pra atau pascaoperasi (Putih, dalam Black, 2004). Pada periode pascaoperasi, mekanisme koping menjadi kelebihan beban akibat hilangnya kepercayaan, kemandirian dan sering pasien mungkin berupaya untuk mengatasi masalah yang berkaitan dengan harkat dan martabat sebagai pasien dengan stoma (Black, 2004). Selanjutnya Offman (dalam Black, 2004) menunjukkan bahwa efek psikologis operasi stoma lebih besar daripada efek fisik atau pun farmakologis. Perubahan pada gambaran tubuh dan berkabung atas kehilangan bagian tubuh akibat tindakan operasi, dapat dipandang sebagai masalah pada fisik ataupun seksual yang mengganggu keutuhan tubuh. Pertimbangan utama dalam hal adaptasi setelah operasi stoma tampaknya akan membutuhkan waktu yang lama dalam proses berduka (Black, 2004).

Masalah lain yang dikemukakan juga oleh informan yaitu adanya perubahan status ekonomi yang juga dirasakan oleh informan setelah dirinya hidup dengan kolostomi. Pada informan walaupun biaya operasi sebagian besar dibiayai oleh jamkesmas, namun bagi informan lima dengan biaya sendiri dengan menjual motor yang dimilikinya. Setelah operasi pun tetap butuh biaya perawatan dan kantong kolostomi, sehingga informan pun tetap membutuhkan biaya yang tidak sedikit, terlebih lagi untuk jangka panjang. Hal ini tetap menjadi beban bagi semua informan baik bagi pensiunan maupun karyawan swasta terlebih lagi bagi informan yang tidak bekerja. Setiap informan mengalami perubahan pada kondisi ekonomi atau keuangan, terlebih lagi bagi informan yang tidak memiliki pekerjaan tetap, sehingga berdampak pada keuangan rumah tangga termasuk dalam hal upaya pemenuhan kebutuhan keluarga.

Kondisi perekonomian yang kurang ini akan berdampak pada terbatasnya pilihan jenis kantong dan terapi bagi pasien. Hal ini juga akan memperberat kondisi penyakit dari informan tersebut. Pasien dengan kolostomi cenderung menghadapi berbagai masalah yang kompleks, seperti perubahan pada fisik, mental, emosional, sosial, seksual serta ekonomi (Panusur \& Rika, 2007).

\section{Simpulan}

Berdasarkan hasil penelitian ini dapat disimpulkan bahwa pengalaman yang dialami 
La Rangki: Pengalaman Hidup Pasien Stoma Pascakolostomi

oleh informan dengan kolostomi berupa keterbatasan dalam melakukan aktivitas sehari-hari, perubahan psikososial informan, perubahan dalam perilaku ibadah atau distres spiritual, berbagai sumber dukungan bagi informan, upaya menjalani hidup dengan stoma, serta penyulit hidup dengan kolostomi.

Hasil penelitian ini menemukan newinsight berupa individu yang hidup dengan kolostomi mengalami distres spiritual. Temuan lain juga terkait dengan kurangnya informasi yang dialami oleh beberapa informan dan kesulitan terhadap akses pelayanan kesehatan dalam menjalani kemoterapi dan radioterapi terutama informan yang berada di luar daerah Bandung.

Hasil penelitian ini dapat juga dijadikan acuan bagi perawat dalam melakukan pengkajian kebutuhan asuhan keperawatan pada pasien pascakolostomi. Selanjutnya hasil penelitian ini juga dapat dijadikan sebagai dasar rujukan bagi penelitian selanjutnya yang berkaitan dengan pengembangan model intervensi panduan ibadah pada pasien dengan kolostomi.

\section{Daftar Pustaka}

Akbulut, G. (2011). Nutrition in stoma patients: A practical view of dietary therapy. Gazi University Faculty of Health Sciences. International Journal of Hematology and Oncology, 21,61.

Black, P. (2004). Psychological, sexual and cultural issues for patients with a stoma. British Journal of Nursing, 13(12), 692-697.

Craven, R. F. \& Hirnle, C. J. (2007). Fundamentals of nursing: Human health and function (3rd Ed.). Philadelphia: Lippincott.

Joshland, E., Brennan, F., Anastasiou, A. \& Brown, A. M. (2011). Developing and sustaining a renal supportive care services for people with end stage renal disease. Renal Society of Australia Journal, 8(1).

Karadag, A., Mentes, B. B., Uner, A., Irkorucu, O., Ayaz, S., \& Ozkan, S. (2002). Impact of stomatheraphy on quality of life in patients with permanent colostomies or illeostomies. Journal of Colorectal Diseases, 18(3), 234-2.

Khan, M. A., Jamal, S., Rashid, S., \& Ahmad, N. (2011). Quality of life assessment in patients with stoma in muslim population. Ann. Pakistan Institute Medical Science, 7(4), 222-227.

Lone, R., Annemette, G., Abild, N., Birthe, L., Thomsen., \& Randi, V. (2007). Quality of life of danish colorectal cancer patients with and without a stoma. Support Care Cancer, $15,505-513$.

Majelis Fatwa Dewan Da'wah Indonesia (2009). Keputusan tentang tatacara ibadah penyandang stoma. Diakses dari http:// www.e-bookspdf.org/download/fatwaislamiyah.html.

McKenzie, F., White, C. A., Kendall, S., Finlayson, A., Urquhart, M., \& Williams, I. (2006). Psychological impact of colostomy pouch change and disposal. $\mathrm{Br} J$ Nurs, 15(6), 308-16.

Panusur \& Rika. (2007). Kemampuan self care dan gambaran diri pasien kolostomi di RSUP. H. Adam Malik Medan. Diakses dari: Repository.usu.ac.id/bitstream.

Sjamsuhidayat, Karnadihardja, W., Rudiman, R., Lukman,K., Ruchiyat, Y., \& Prabani, C. (2006). Panduan pengelolaan adenokarsinoma kolorektal. Jakarta: PT. Roche.

Taylor, C., Lillis, C., \& Lemone, P. (1997). Fundamentals of nursing: the art and science of nursing care (3rd Ed.). Philadelphia: Lippincott.

Vujnovich, A.(2008). Pre and postoperative assessment of patients with a stoma. Nursing Standard: Nursing \& Allied Health Source.

White, C. A. (1997). Living with a stoma: A practical guide to coping with colostomy. Journal of Advance Nursing, 16, 1400-5. 
La Rangki: Pengalaman Hidup Pasien Stoma Pascakolostomi

World Health Organization. (2008). dari: http://globocan.iarc.fr/. Diakses pada 30 Colorectal cancer incidence, mortality and Oktober 2012.

prevalence worldwide in 2008. Diperoleh 